\title{
A review on molecular neuropathology of Alzheimer's disease in association with aging
}

\author{
Tutun Das AKA ${ }^{1}$, Md. Mamun Or RASHID ${ }^{1}{ }^{*}$, Shujit Chandra PAUL ${ }^{2}$, Md. Abdul HALIM ${ }^{1}$ \\ 1 Department of Pharmacy, Noakhali Science and Technology University, Sonapur, Noakhali-3814, Bangladesh. \\ 2 Department of Applied Chemistry and Chemical Engineering, Noakhali Science and Technology University, \\ Sonapur, Noakhali-3814, Bangladesh. \\ * Corresponding Author. E-mail: mamun_nstu@yahoo.com (M.M.O.R.); Tel. +880 1911141120; ORCID No: 0000- \\ 0002-3555-6354.
}

Received: 03 March 2018/ Revised: 17 September 2018 / Accepted: 18 September 2018

\begin{abstract}
Alzheimer's disease (AD) is a chronic neurodegenerative disease where learning and memory deficit occur. Aging is the main culprit responsible for this disease. Many hypotheses have been proposed for explaining the neuropathology of AD. Amyloid cascade hypothesis states that AD may cause due to neuronal damage by forming senile plaque of beta amyloid $(A \beta)$ and followed by the formation of neurofibrillary tangles (NFTs). Due to mismetabolism of amyloid precursor protein (APP), A $\beta$ aggregates and initiates AD. Mitochondrial cascade hypothesis emphasize on mitochondrial dysfunction in aged brain which starts by rising $A \beta$ accumulation, later tau hyperphosphorylation and inflammation, and finally development of AD. According to the calcium hypothesis, dysregulation of neuronal $\mathrm{Ca}^{2+}$ signaling incurs apoptosis of neuronal cells that interrupts cognitive functions and initiates AD. Tau hypothesis propose that aggregation of tau protein may lead the formation of NFTs which is a pathological hallmark of AD. Oxidative stress hypothesis states that brain aging increase the production of lipid peroxides and reactive oxygen species by elevating oxidative stress level which causes $\mathrm{AD}$. In aged brain, accumulation of oxysterol due to impairment of Blood Brain Barrier (BBB) may lead to formation of AD which is purported in cholesterol hypothesis. Again, neuroinflammation hypothesis says that immune system's cell injury occurs in AD which plays a dominating role in AD inflammation. However, the mechanism of neuropathology of AD remains poorly understood still now. This review critically evaluates different hypotheses which may become helpful for the future researchers to scrutinize more acceptable molecular neuropathology of AD.
\end{abstract}

KEYWORDS: Beta amyloid (A $\beta$ ); senile plaque (SPs); tau; $\mathrm{Ca}^{2+}$ signaling; reactive oxygen species (ROS); ryanodine receptors (RyR).

\section{INTRODUCTION}

Alzheimer's disease (AD) is a progressive and chronic neurodegenerative disease. It starts slowly and become devastating with aging. Although the most common outcome of AD is loss of memory, it may affect the mood and personality also. Nowadays this disease is taken with high consideration, because there is no permanent treatment of this disease. Almost 35 million patients suffer in AD disease globally. This number of patients is particularly high in USA; a new AD patient is diagnosed per 66 seconds at present time and by 2050, the number of new AD patients will be approximately one million per year in USA. However, the mechanism of the initiation of $\mathrm{AD}$ remain poorly understand yet. In $\mathrm{AD}$, extra-cellularly occurred beta amyloid $(\mathrm{A} \beta$ ) plaque and intra-cellularly formed hyper phosphorylated tau protein may accumulate in brain in forms of neurofibrillary tangles (NFTs) $[1,2]$. Both the accumulated A $\beta$ oligomers and tau protein aggregates are cytotoxic which are responsible for $\mathrm{AD}$ development. It is evident that $\mathrm{A} \beta$ oligomers drive the tau formation and followed by dysfunction of mitochondria which in turn resulting in oxidative stress. Some other factors, i.e.- increased level of cytosolic calcium, cholesterol in neuronal membrane and inflammation are also act as triggering agents for the development of $\mathrm{AD}$ [1]. Beside these, some genes are also responsible here- Amyloid precursor protein (APP), Presenilin 1 (PSEN1), Presenilin 2 (PSEN2), Apolipoprotein E (APOE).

AD is mainly two types. They are: early onset Familial Alzheimer's Disease (FAD) which may developed in early age ( $\sim 5$ years); and another one is late onset Sporadic Alzheimer's Disease (SAD) which occurs with aging usually after 65 years and its incidence is found to be double in every five years after this

How to cite this article: Aka TD, Rashid MMO, Paul SC, Halim MA. A review on molecular neuropathology of Alzheimer's disease in association with aging. J Res Pharm. 2019; 23(1): 1-15. 
age mark [1,3]. SAD is most common among the patients, whereas $<1 \%$ patient of AD suffer in FAD. In this age related disease, brain atrophy causes and this includes- hippocampal atrophy, neocortical atrophy, entorhinal cortex atrophy, subcortical structures atrophy, white matter lesions, white matter tract changes [4].

The primary aim of this review is to study the possible reasons of AD. In this aspect, we try to accumulate and organize the most popular hypotheses described for explaining the initiation of $\mathrm{AD}$. In addition, we try to find out the reasonable correlation of aging with the development of AD.

\section{METHODS}

In this review, we have used PubMed, DOAJ, CABI, CAS, Medline, Global Health etc. In addition, we use google search engine for getting internet information and selecting our articles regarding Alzheimer's disease from the renowned journals. We had initially selected about 313 articles having keywordsAlzheimer's disease (17 articles), Amyloid cascade Hypothesis (39 articles); Mitochondrial Cascade Hypothesis (32 articles); Calcium Cascade Hypothesis (36 articles); Tau Hypothesis (58 articles); Hypothesis of Oxidative stress (45 articles); Cholesterol and AD (31 articles); Neuroinflammation in AD (34 articles) and Age causing AD ( 21 articles). From these articles we had excluded 225 articles considering the overlapping of the backward information. Finally our selected 86 articles included- review article (46), research article (32), in-vitro experimental study (1), controlled clinical trial (2), multicenter study (1), case report (3), comparative research article (1). The literature survey was performed for the articles published within 1984-2018. We use SmartDarw 2013 for drawing most of the figures.

\section{MOLECULAR NEUROPATHOLOGY OF ALZHEIMER'S DISEASE}

Many hypotheses have been proposed at different times for explain the mechanism of AD (Figure 1). Based on accumulation of amyloid beta in brain, amyloid cascade hypothesis (ACH) had proposed first for $\mathrm{AD}$ [5]. Later, many other hypotheses also proposed in different times. This article explains seven main hypotheses of $\mathrm{AD}$ development.

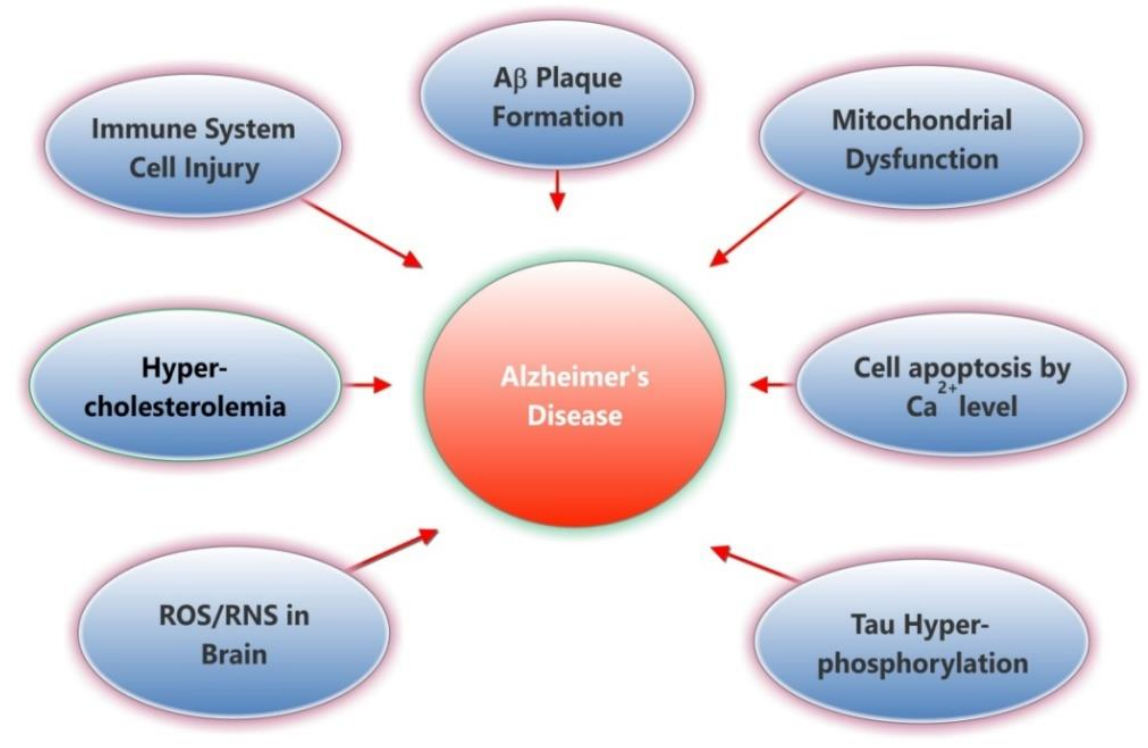

Figure 1. The proposed causes of AD according to different hypotheses.

\subsection{Amyloid Cascade Hypothesis}

According to amyloid cascade hypothesis $(\mathrm{ACH}), \mathrm{AD}$ is mainly caused by the deposition of beta amyloid $(A \beta)$ in the brain parenchyma. Early onset familial Alzheimer's disease (FAD) is caused by autosomal dominant mutation. Three genes- PSEN 1, PSEN 2 and APP are responsible for this mutation. In brain, the correlation of $\mathrm{AD}$ and $\mathrm{A} \beta$ accumulation (amyloid plaques formation) is not linear [6]. $\mathrm{ACH}$ suggests that due to mismetabolism of APP formation in neurotic plaques, A $\beta 42$ produces which leads to the formation of NFTs followed by synaptic disconnection. This anomaly incurs the reduction of neurotransmitter which is followed by the death of tangle bearing neurons. The result of these consequences is the development of AD [7]. This hypothesis also suggests that $A \beta$ is the initial neuropathological component of $A D$, and its vast mutation leads 
the familial early onset Alzheimer's disease (EOAD) where fibrillogenic $A \beta 42$ ratio is increased [8]. Large amount of $A \beta$ in the cell is neurotoxic which leads to mitochondrial dysfunction-apoptotic genes inductionion channel formation-loss of calcium homeostasis triggering-microglia cell activation-increase ROS-neuronal toxicity-finally cell death [9-14]. A $\beta$ level is regulated by amyloid degrading enzymes and $A \beta$ removes from brain by endocytosis. Dysfunction of this endocytosis process is a common pathology for sporadic AD [15]. A $\beta 42$ accumulation may be the risk factor for late onset Alzheimer's disease (LOAD) [8]. Soluble form of A $\beta$ levels is correlated with severe AD than insoluble form [16]. Current study noticed that not only intraneuronal A $\beta 42$ accumulation occurred in neuronal cells but also A $\beta 42$ immunoreactive senile plaque (SPs) development is occurred at the terminal of neurons [17]. The transgenic animal study suggests that hippocampal synaptic efficiency of brain is altered by the soluble $A \beta$ level. In this case $A \beta 42$ expression is increased, and then age dependent learning deficit occurs which develops magnificent neurodegeneration finally [18-20].

$\mathrm{ACH}$ has also stated that missense mutation of APP, PSEN1 or PSEN2 gene occurred in amyloid containing brain region. In mouse, $A \beta$ influence tau pathology formation by affecting tau kinase through the inhibition of insulin and signaling, which negatively regulate the glycogen synthase kinase-3B (GSK 3B) activity and followed by increase of the $\mathrm{AD}[11,21,22]$. On the other hand, $\mathrm{AD}$ is related with axonal transport deficiency, and any dysfunction of axonal transport may develop AD. APP is the receptor of kinesin light chain (KLC), and kinesin dependent transport inhibited by tau which leads selectively increase of A $\beta 42$ peptides. Tau level is increased due to neuronal degeneration [23-25].

There are two main observations in ACH. Firstly, A $\beta$ detects as main component of SPs. Secondly APP, PSEN 1 and PSEN 2 genes mutations are found in FAD or EOAD [26, 27]. The fear of the rejection of ACH is due to the inconsistency of basic linear structure of this hypothesis with growing amount of data for defining and diagnosing $\mathrm{AD}[28]$.

\subsection{Mitochondrial Cascade Hypothesis}

Mitochondrial cascade hypothesis $(\mathrm{MCH})$ assumes that the consequences of sporadic and late onset $\mathrm{AD}$ are: APP processing-expression and accumulation of $\mathrm{A} \beta$-mitochondrial function is affected-mitochondrial function triggers from amyloid cascade. The firstly proposed (2004) MCH possesses three parts- (1) Baseline mitochondrial function of an individual is defined by individual's gene inheritance (2) Mitochondrial changes occurred with aging and its rate can determine by inherited and environmental factors (3) Initiation of individuals $\mathrm{AD}$ chronology is influenced by the significant change rate of their mitochondrial functions.

According to $\mathrm{ACH}$, brain aging is mechanistically related with $\mathrm{AD}$ where a mitochondrial activity constitutes a crucial link. AD is not initiated by the accumulation of toxic cascade $\mathrm{A} \beta$ but by the mitochondria. $\mathrm{A} \beta$ is not an upstream biomarker of $\mathrm{AD}$, but is a downstream marker of mitochondrial dysfunction. This hypothesis proposed that mitochondrial function declined with aging and then AD occurs (Figure 2). Hence, $\mathrm{A} \beta$ is the more prominent downstream biomarker of brain aging. However, $\mathrm{ACH}$ states that $\mathrm{A} \beta$ is the primary upstream biomarker of AD. In LOAD, AD pathologies are initiated and drive by mitochondria [29]. Again, tau pathology and mitochondrial dysfunction involved in $\mathrm{AD}$ and here with tau pathology, mitochondrial dysfunction has been strongly associated. In addition, mitochondrial dynamics is impaired by pathological tau through the regulation of mitochondrial fission/fusion protein [30].

This hypothesis also states that both LOAD and autosomal dominant FAD, mitochondrial dysfunctions occurred. In this occasion, there are two types of brain aging exist- compensated and uncompensated. Symptomatic AD temporally coincides with uncompensated brain aging which represents the stage of aging [31]. Coskun et al. states that the tendency of rising of mutation level is found in somatic mtDNA control region of $\mathrm{AD}$ affected brain. Here, mtDNA deletion level is elevated by some groups mainly by the mtDNA cox genes. When this mtDNA deletion level is increased, other neurodegenerative diseases occurs along with $\mathrm{AD}$ [32-36]. Among the various inconvenient implications of $\mathrm{MCH}$, the main implications are early onset autosomal dominant and late onset non-autosomal dominant where AD doesn't share a common etiology [37]. 




Figure 2. $\mathrm{MCH}$ explanation for the genesis of $\mathrm{AD}$.

\subsection{Calcium Cascade Hypothesis}

Calcium cascade hypothesis $(\mathrm{CCH})$ can be explained by two ways- amyloidogenic pathway and remodeling of neuronal $\mathrm{Ca}^{2+}$ signaling pathways which are responsible for cognitive deficits. The resultant two major products of the hydrolysis of $\mathrm{A} \beta$ can influence the $\mathrm{Ca}^{2+}$ signaling. One of these products is amyloids which can enhance the $\mathrm{Ca}^{2+}$ entry into the endoplasmic reticulum (ER). High level of $\mathrm{Ca}^{2+}$ in ER increase the sensitivity of ryanodine receptor (RYR), which further increase the release of $\mathrm{Ca}^{2+}$ from internal stores. Another one is APP which alters the expression of RYR and increases the release of $\mathrm{Ca}^{2+}$. As a result, learning and memory deficit occur which lead to initiate AD finally [38]. According to the $\mathrm{CCH}$, one of the main reasons of $\mathrm{AD}$ is- dysregulation of calcium signaling [39]. Calcium is the second messenger of nervous system which involves in membrane excitability and different biological functions of the neuron. Two main proteins are related with $\mathrm{AD}$ (40-42 long $\mathrm{A} \beta$, and tau protein) [40].

Calcium is necessary for different plastic changes in brain including learning and memory processes. $\mathrm{CCH}$ stated that if intracellular free $\mathrm{Ca}^{2+}$ (increased with aging) can be reduced, it is possible to reduce the rate of neuronal losses, and relieve from $\mathrm{AD}[38,41,42]$.

$A \beta$ is formed from APP by the intracellular cleavage ( $\gamma$-secretase cleaved at C-terminal, whereas $\beta$ secretase cleaved at $\mathrm{N}$-terminus). $\gamma, \beta$, and $\varepsilon$ secretase is linked with amyloidogenic pathway, while asecretase is related with non-amyloidogenic peptide formation pathway [43, 44]. Due to the activation of amyloidogenic pathway, AD developed which is shown in Figure $3(3 a, 3 b)$. $\mathrm{Ca}^{2+}$ level are increased at different sites- mitochondria, pyramidal neuron etc. It also increases ROS production which incurs apoptosis and finally development of $\mathrm{AD}$. $\mathrm{Ca}^{2+}$ level increases in ER, presenilin enters into the endosomes and golgi bodies. These cell apparatus then secretes $\gamma$-secretase complex which is responsible for $A \beta 42$ formation and release of APP intracellular domain (AICD). They can cause remodeling of the $\mathrm{Ca}^{2+}$ signaling system and finally $\mathrm{AD}$ is developed. 


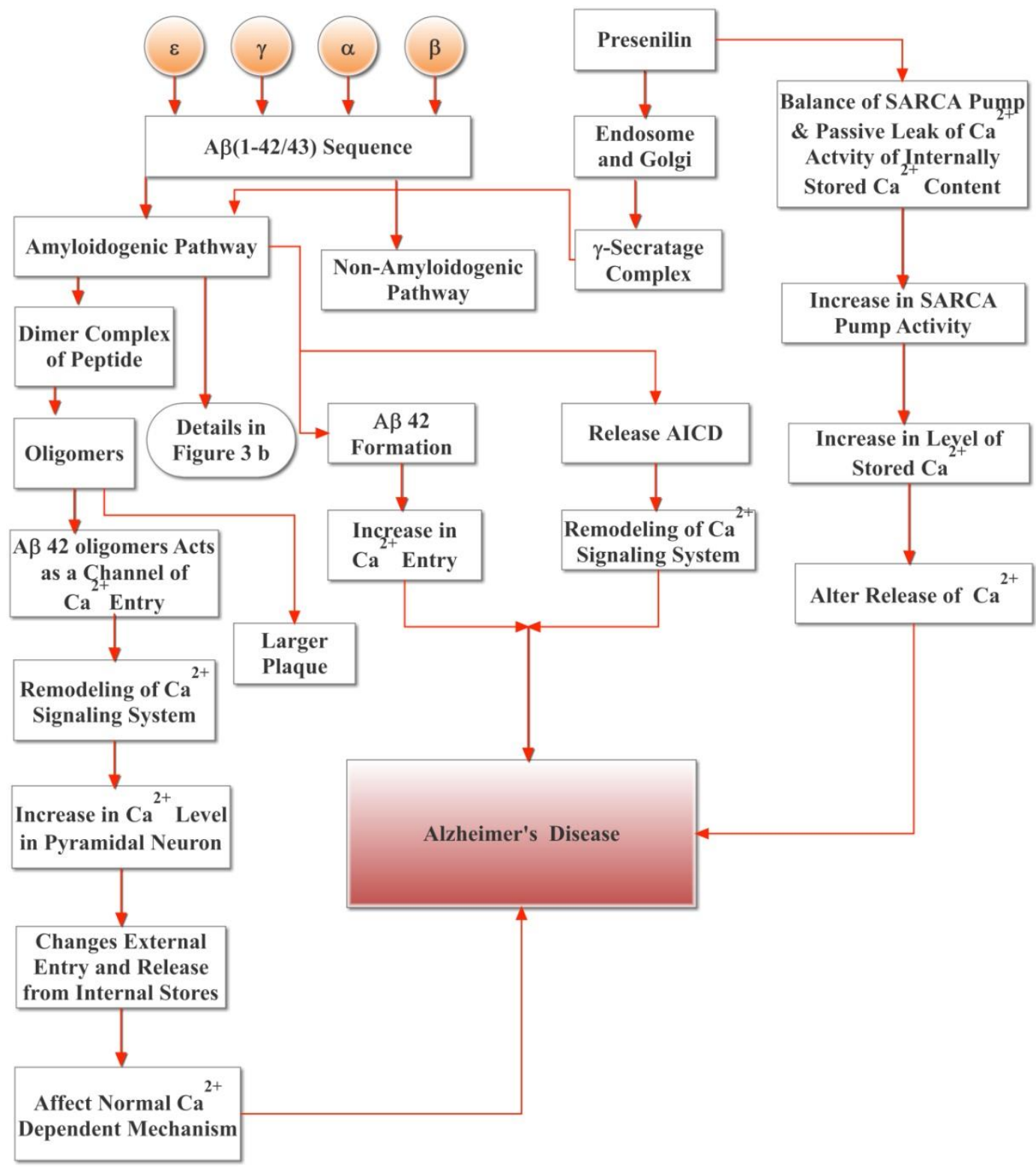

Figure 3a. Role of $\mathrm{Ca}^{2+}$ in development of $\mathrm{AD}$.

Presenilin can also affect balance of sarco-endoplasmic reticulum $\mathrm{Ca}^{2+}$ ATPase (SERCA) pump and increases its activity. Later, it may increase the level of stored $\mathrm{Ca}^{2+}$ and finally it causes AD. Again N-terminal of APP (N-APP) is a ligand for orphan DR6 receptor which is a super-family member of tumor necrosis factor (TNF) receptor. It activates caspase 3 receptor which triggers apoptosis. As a result, amyloidogenic pathway is stimulated which increases sAPP $\beta$-formation followed by increasing cell death and $\mathrm{AD}$ development [38]. In mouse model, calcium storage was found to be dysregulated at the presynaptic side and nerve cell activity was increased abnormally. As a result, large amount of neurotransmitters releases into the cerebral cortex. It causes nerve cells hyperactivity and ultimately leads to the development of AD [45]. 


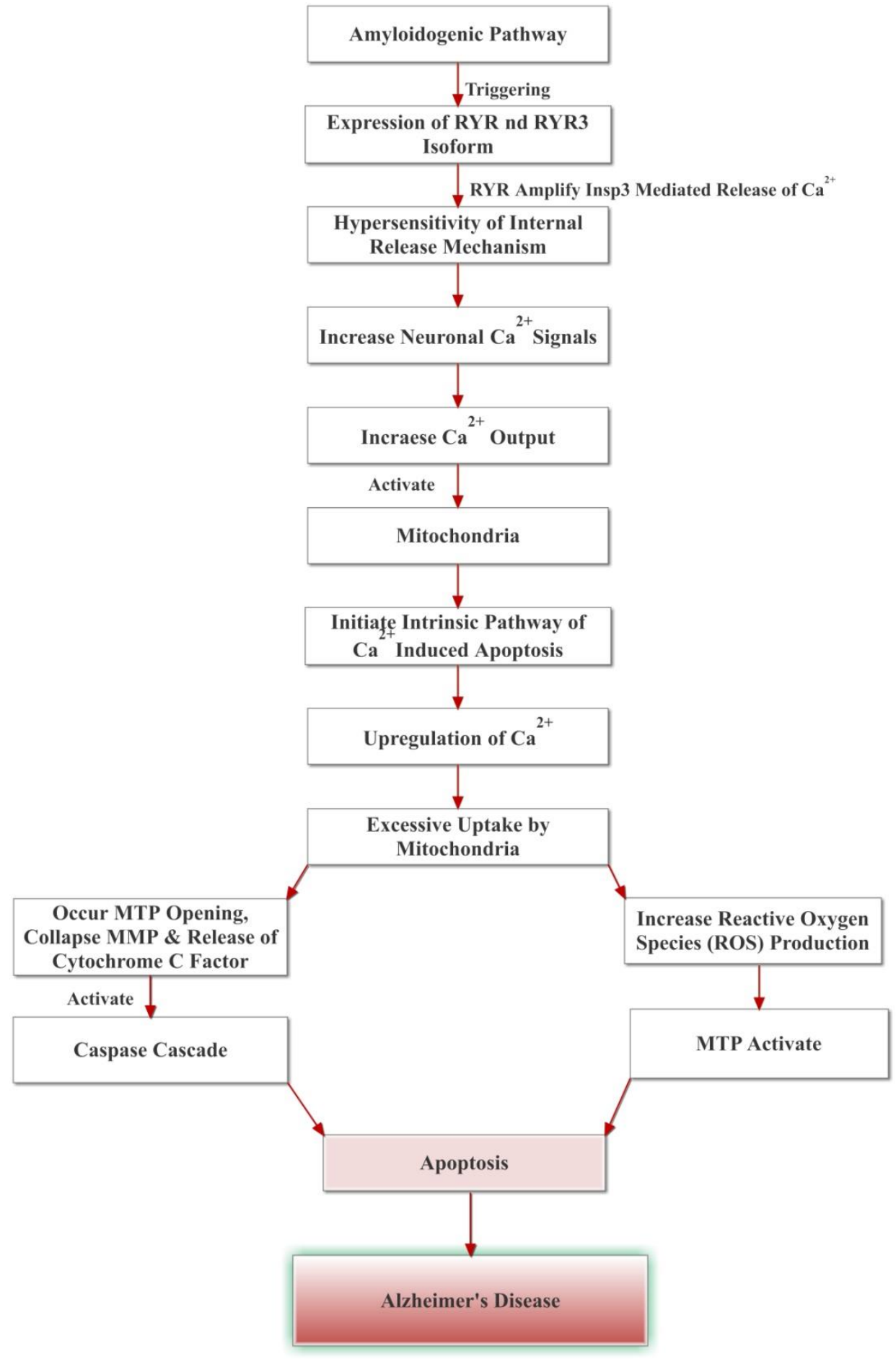

Figure $3 \mathbf{b}$. Role of $\mathrm{Ca}^{2+}$ in development of AD.

\subsection{Tau Hypothesis}

Due to the production of two abnormal proteins (tau and beta-amyloid), AD may developed in the brain [46]. Tau is an intracellular protein produced in the microtubules of axon. It has an important role in cellular structure of neuron and also in microtubules. Microtubules of the axon help to pass nutrients, waste, and chemical transmitters through neuron. Tau plays a critical role in stabilizing microtubules, but unfortunately this stability is destroyed in $\mathrm{AD}$ [47]. In $\mathrm{AD}$, tau is separated from the microtubules and then hyperphosphorylated. This hyperphosphorylated tau forms insoluble fiber and different aggregate structures $[48,49]$. As a result, this protein can damage cytoplasmic function of neuron and axonal transport of neuron 
which incurs cell deaths and genesis of AD [50]. Again in a healthy mouse brain it was found that if abnormal tau protein is injected, it spreads quickly and then leads to manifestation of dementia symptoms [46].

\subsubsection{The sequence of tau responsible for $A D$}

Recently it has been found that tau oligomer is an attractive target for AD pathogenesis. Lasagna-Reeves et al. studied on mice model and found that tau oligomer can induce more neurotoxicity than tau monomers and fibers. We know that every neuron possesses two sequences- amino terminal sequence and carboxyl terminal sequence. In-vivo study confirmed that the carboxyl terminal of microtubule-binding domain (MTBD) of tau protein is responsible for neurotoxicity. And this terminals form NFTs core in pathological condition of AD [47].

\subsubsection{Relationship between tau protein and $A D$}

Tau in pathological condition (hyperphosphorylated tau: a modified variant of tau), can cause neurodegeneration as well as AD development by forming NFTs and inflammatory cascade cycle respectively. Recently studies found that hyperphosphorylated tau triggers neurotoxic action which affects normal interaction pattern of neuronal cytoskeleton. In pathologic condition, tau oligomerization causes cognitive impairment due to neuronal death; and Figure 4 describes the mechanism schematically. Tau can interact with microtubules by positive charge of tau. By blocking tau polyanion in interaction sites, stable microtubules can prevent PHF formation [51, 52].

According to this hypothesis, tau oligomers are increased before exposing clinical symptoms of AD. There are some factors which can cause tau hyperphosphorylation- iron overload, hyperglycemia, lipid metabolism disorders, insulin level deregulation, head trauma etc. These factors activate endogenous alarm signal which triggers abnormal cellular signaling of astrocytes and microglial cells. This activated glial cells release nuclear factor kappa B (NF-KB) and cause overproduction of pro-inflammatory cytokines (TNF $\alpha$, IL6, IL-1 $\beta$ ) which leads brain inflammation. Not only pro-inflammatory cytokines but also overproduction of complement components and free radicals are found in activated glial cells. All of these factors potentially contribute neuronal dysfunction and later cell death. In Figure 4, we see that overproduction of Interleukin-6 (IL-6) causes AD development. Through the production of nerve growth factor (NGF), A $\beta$ activates astrocytes p75 [52]. Tau protein is essential for inducing $A \beta$ pathogenesis. In addition, it also plays as downstream effectors of $A \beta$ cascade $[47,53]$. In $A D$ patient, the overall brain neurons connection is lessened due to high amount of tau [46].

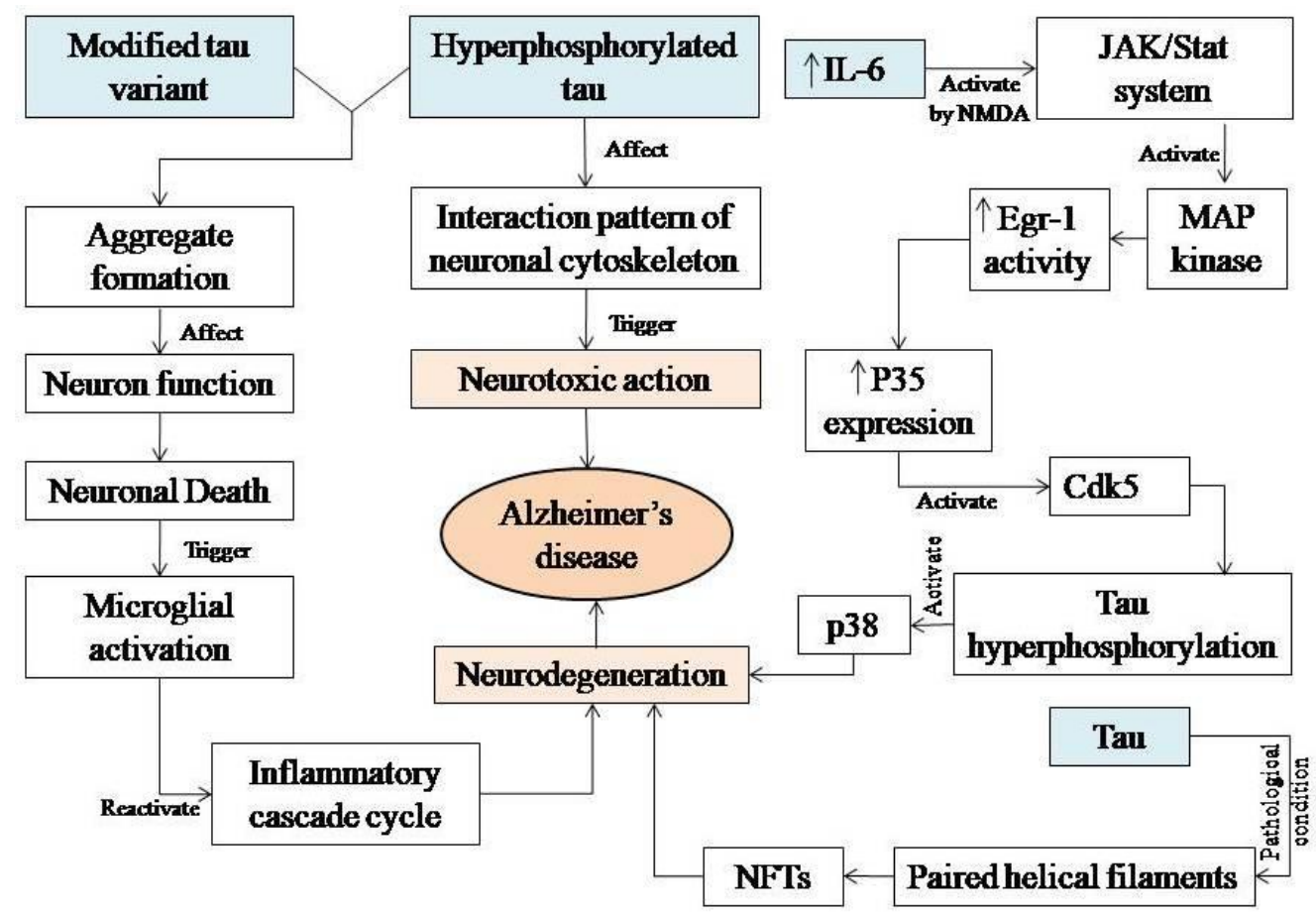

Figure 4. Tau activities in AD development. 


\subsection{Hypothesis of Oxidative stress}

Oxidative stress causes due to imbalance of reactive oxygen species (ROS)/ reactive nitrogen species (RNS) reduction and antioxidant generation [54]. Studies show that free radical is involved in etiopathogenesis of AD. Excess accumulation of free radicals in brain can reduce antioxidant reservation and increase lipid peroxidation level which is followed by resulting AD [55]. This hypothesis exclaims that oxidative damage is the early event of $\mathrm{AD}[56]$.

\subsubsection{Source of free radicals}

The main source of free radical is electron transport chain (ETC) of mitochondria [54]. Due to aging, synthesis of free radical increases. Excess free radical causes the defects, and dysfunction of mitochondrial membrane. It causes defects in respiratory chain and increases the formation of ROS (55). Other sources of ROS and RNS are astrocytes and microglia which are activated by metal ions such as- copper and zinc [57]. $\mathrm{A} \beta$ can also increase the production of ROS in brain and cause mitochondrial damage which further increase ROS production. So, $\mathrm{A} \beta$ have a clear relationship with oxidative stress [58].

\subsubsection{Oxidative stress and neurotoxicity}

Oxidative stresses can induce AD via different ways. Metal dependent enzymatic process is very important for the metabolism of brain; however it is disrupted in AD brain [59]. Biometals such as- iron, zinc, copper etc. play important roles in production of $A \beta$ and neurodegeneration. In amyloid plaque, a high concentration of copper is found. This copper is the potent mediator for highly reactive hydroxyl radical (OH $)$. $\mathrm{A} \beta(1-42)$ is more toxic than $\mathrm{A} \beta$ (1-40) which produces ROS and hydrogen peroxide [55, 60]. Zinc homeostasis is disrupted in $\mathrm{AD}$ [61]. Presence of high concentration of zinc in memory and cognitive regions of brain can cause cognitive impairment by producing different toxicants, fibrillaries and $A \beta$ aggregates. Moreover, zinc and iron can bind with tau protein and promote aggregation and phosphorylation of tau [60,62]. A $\beta$ can increase the oxidative stress in-vitro due to its ability of iron binding. It can destabilize the lysosomal membrane which results the death of cells. ROS/RNS denature macromolecules in human body by pathological redox reaction which results $\mathrm{AD}$ (Figure 5) [63, 64]. In AD brain, $\mathrm{A} \beta$ bind with mitochondrial $\mathrm{A} \beta$ binding alcohol dehydrogenase (ABAD) receptor and increases ROS production which is followed by mitochondrial dysfunction and apoptosis [10, 58, 65]. Free radicals induce neuronal death when attach with neuronal fat. As a result, the membrane permeability, fluidity, transport and barrier like functions may changes. Lipid is another important target of oxidative stress. Due to lipid peroxidation, Malondialdehyde (MDA) produces as byproduct which reacts with DNA strands [55]. Oxidation of the brain affects DNA and breaks the strands which result sister chromatid exchanges, cross linking in DNA proteins, and modification of bases.

Oxidative stresses form carboxyl protein from protein molecule. In AD brain, aggregate proteins lead to the formation of fibrils which are aggregation and hyperphosphorylation of tau protein mainly [60]. In addition, when lipid peroxidation increases in brain, ROS level also increases by 4-hydroxy-2-nonenal and isoprostanoids. As a result, carboxyl protein also increases and neurons survival ratio decreases.

Again oxidative stress triggers other pathologies which are associated with risk factors of AD, such as ApoE4 genotype, insulin resistance and type 2 diabetes mellitus. There is a relationship between the pathophysiological mechanisms of type 2 diabetes and $\mathrm{AD}$; oxidative stress plays an important role in these conditions. In addition, through the insulin-degrading enzyme (IDE) hyperinsulinemia may stop the degradation of extracellular beta amyloid [56].

\subsubsection{Oxidative stress and genetic factor}

Oxidative stress also influences on gene expression. When oxidative stress increases, some genes such as- E4 allele is also stimulated which increases the expression of Apolipoprotein E. Free radicals act as mediator of gene expression. Increment of Apolipoprotein E expression incurs the negative effect on neuronal plasticity processes such as- learning and memory deficit which may lead to initiation AD [55]. 


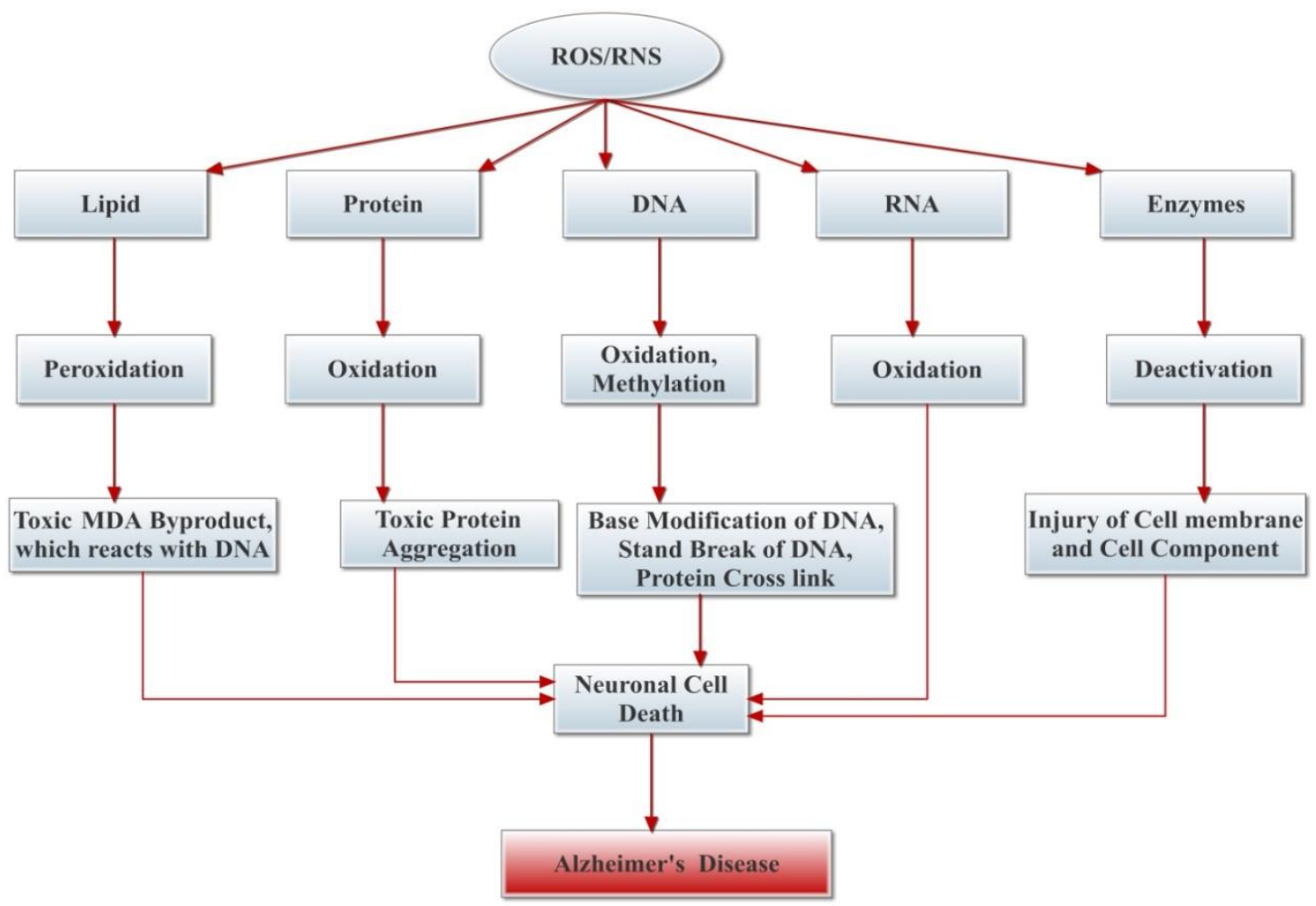

Figure 5. Effect of ROS on AD though targeting different biological molecules.

\subsection{Cholesterol and AD}

Cholesterol is the one of the major constitute of human brain. It's amount in brain is significantly regulated by the neurons, glial cells (astrocytes, microglia, and oligodendrocytes). It is necessary for the proper functioning of synapse, dendrite, axon, and neuronal cell membrane formation. Defective cholesterol metabolisms may lead AD [66].

\subsubsection{Relationship between cholesterol and $A D$}

Cholesterol can be produced in brain. However, alteration of the cholesterol metabolism and hypercholesterolemia is the potential risk factors of $\mathrm{AD}[67,68]$. For preventing cholesterol accumulation in brain, body itself oxidized cholesterol by the activities of cytochrome P450 enzymes. Due to metabolism, oxysterols including 24-hydroxycholesterol $(24-\mathrm{OH})$, and 27-hydroxycholesterol $(27-\mathrm{OH})$ are produced by CYP27A1 enzyme. Then, it is transformed by CYP7B enzyme into 7a-hydroxy-3-oxo-4-cholestenoic acid (7$\mathrm{OH}-4-\mathrm{C}$ ). Both of these oxysterols can cross the blood brain barrier (BBB), 24-OH can go to the systemic circulation; and $27-\mathrm{OH}$ is eliminated after being reached into the liver. However, major amount of 27-OH flows to the opposite direction and accumulates into the brain. These oxysterols were found in post-mortem of AD patients $[67,69]$. In healthy brain, oxysterol homeostasis is closely controlled by cholesterol biosynthesis, efflux and formation pathway of oxysterols. In contrast, in aged brain with AD, BBB dysfunction occurs in brain which may change the homeostasis of cholesterol. As a result, notable amount of toxic oxysterols are accumulated. It can interrupt the BBB functions by damaging its integrity. Moreover, oxidative stress with hypercholesterolemia induces BBB damage. In addition, oxysterols or 27-hydroxycholesterol can increase sAPP production in brain CNS. It may incurs amyloidogenesis which is considered as a strongest reason of $\operatorname{AD}[67,70]$. Again, cholesterol plays a specific catalytic role in the $A \beta 42$ aggregation. Membranous cholesterol promotes $A \beta 42$ accumulation through a heterogeneous nucleation pathway which results in enhancement of primary nucleation rate up to 20 -fold. Onset of $A \beta 42$ accumulation is dramatically enhanced by the cholesterol through a specific microscopic pathway [71].

\subsection{Neuroinflammation in AD}

Recently it has been found that innate immune system plays a dominating role in AD inflammation [72]. Immune system cell injuries occur in AD. Neurons, astroglial, microglial cells are destroyed in AD which leads to produce chemokine and inflammatory mediators of cytokine. $\mathrm{A} \beta$ and tau act as pro-inflammatory factor of 
$\mathrm{AD}$ [73]. $\mathrm{A} \beta$ stimulates pro-inflammatory gene expression in microglial cell by activating mitogen-activated protein kinases (MAPKs). MAPK secretes cytokine and chemokine which can initiate inflammation [74].

Two main barriers- BBB and blood cerebrospinal fluid barriers (BCSFB) also involve in AD. Due to the impairment of those barriers, chemokine can be infiltrated through the barriers [75]. T-cell of the innate immune system plays protective role in $\mathrm{AD}$. However, many research reports prove that $\mathrm{T}$-cell plays special role in neuroinflammation development of $\mathrm{AD}$; although the mechanism of this action is not clear. One possible reason is- $T$-cell can prevent the development of $A \beta$ plaque (A $\beta 1-40)$. On the other hand, $A \beta 1-42$ (a specific T-cell) is found in AD patients. A $\beta$ specific Th1 cell can produce pro-inflammatory cytokines; whereas $\mathrm{A} \beta$ specific Th2 cells inhibit cytokine production. Hence it is thought that in different stages of AD, T-cell plays contradictory roles in EOAD and LOAD [76].

\subsection{1. $T$ cell and immune mediator of $B B B$ in $A D$}

In $\mathrm{AD}, \mathrm{BBB}$ permeability and infiltration of immune cell from periphery into the CNS increases. Cerebral amyloid angiopathy (CAA) is a specific feature of $A D$ where $A \beta$ accumulation and deposition are increased in neurovascular unit. The development of CAA could be defined by two different mechanisms. At first, A $\beta$ efflux is increased into the brain parenchyma due to over expression of the advanced glycation end products (RAGE) receptors which are located in the endothelial cells of BBB. As a result, $A \beta$ concentration and cellular stress increases. Second one is the failure of $A \beta$ clearance. This is due to decreased level of expressed low density lipoprotein receptor 1 (LRP-1) in endothelium cells and decreased level of P-glycoprotein (P-gP) in plasma membrane of brain endothelium. A $\beta$ efflux may reduce from the blood of brain $[77,76]$. AD increases the transmigration of immune cells. As a result, immune cells or T cells can in-filter through BBB. There are evidences that dendritic cells are influenced by $A \beta$ specific $T$-cells to infiltrate the $A \beta$ plaque into the brain. A $\beta$ 1-42 activate microglial release of TNF- $\alpha$ which increase expression of transforming growth factor (TGF)$\beta 1$ in astrocytes. The overproduction of TGF- $\beta 1$ reduces $A \beta$ accumulation, but increases cerebrovascular amyloidosis and neuroinflammation [76, 78]. According to McManus et al., infiltrate T-cell produces interferon gamma (IFN- $\gamma$ ) which can promote neuroinflammation by glial activation. During AD progression, not only Th1 cell but also Th17 cells can infiltrate into the brain from blood circulation [79].

\section{EFFECT OF AGE IN DEVELOPMENT OF AD}

$\mathrm{AD}$ is usually related with the loss of learning and memory. It is one of the most alarming diseases related to brain aging. Different hypotheses explain the effect of age upon AD. Here, we try to discuss the effect of age on AD development on the basis of proposed hypotheses.

According to Amyloid cascade hypothesis, due to increase of the age, mutation of APP gene occurs which results the formation of $A \beta$ plaque and NFTs. Later, dysfunction of cognition occurs which leads to neuronal death finally. Mitochondrial cascade hypothesis states that brain aging is responsible for the mitochondrial dysregulation which initiates oxidative stress in brain. As a result, fuel storage energy level (an important phenomenon for surviving neuron) decreases which leads neuronal loss finally [80-83]. According to the calcium cascade hypothesis, $\mathrm{Ca}^{2+}$ regulation may impair in aged brain which leads to the development of $\mathrm{AD}$. One proposal of $\mathrm{Ca}^{2+}$ hypothesis is that if L-type voltage-gated calcium channels (L-VGCC) activity increases, it drives many $\mathrm{Ca}^{2+}$ related biomarkers of hippocampus aging. Other studies have reported that in aged brain $\mathrm{Ca}^{2+}$ release is altered by ryanodine receptors (RyR) of intracellular stores. The $\mathrm{Ca}^{2+}$ sensitive RyR channels amplify plasmalemmal (plasma membrane) $\mathrm{Ca}^{2+}$ influx by the mechanism of $\mathrm{Ca}^{2+}$-induced $\mathrm{Ca}^{2+}$ release (CICR) [84]. This increase of $\mathrm{Ca}^{2+}$ level can causes apoptosis via different ways which leads to initiate $\mathrm{AD}$ [38]. Oxidative stress hypothesis says that the presence of different metal ions in closely related with the proper brain functioning, learning and memorizing. Due to aging of brain, metal homeostasis is disrupted; and metals such as iron, zinc, copper are aggregated. When the metal homeostasis of brain is disrupted, it contributes to initiate oxidative stress which is followed by the development of AD [85]. Cholesterol hypothesis states that in normal brain, oxysterols homeostasis is closely controlled. However due to aging of brain, BBB's integrity is partially disrupted which results to increase the permeability of BBB. That's way cholesterol or oxysterols flux in brain increases from the peripheral blood circulation. Toxic amount of oxysterol is accumulated which plays a fundamental role in development of $\mathrm{AD}$ development by increasing oxidative stress and inflammation $[67,73,76]$. 


\section{CONCLUSION}

$\mathrm{AD}$ develops with brain aging; aging is inescapable and ever-progressing phenomenon of all living organisms after birth. The exact neuropathology of AD is unknown still now; however different hypotheses have been proposed. In this review, we tried to accumulate the proposed hypotheses of AD. Due to aging pathological changes occur in brain, such as- $A \beta$ accumulation, tau hyperphosphorylation, organelle dysfunction, neuronal cells damage etc. The relationships of AD with these changes have been explained by different hypotheses. Based on these hypotheses, some drugs have been designed; however most of them are now in clinical trial stages. Aducanumab (BIIB037), BAN2401 are monoclonal antibodies active against A $\beta$ aggregation [86]. ALZT-OP1 is designed for blocking $\beta$-amyloid aggregation. Dantrolene is also such a newly developed drug on the basis of calcium hypothesis. It is a RyR antagonist and can moderate the amyloid pathway and cognitive impairment [2]. Further study should be continued to find the exact mechanism of AD development, which might be helpful for the drug development program properly.

Acknowledgements: The authors show gratitude to the authority of Noakhali Science and Technology University for providing logistic supports and internet facilities for this research work.

Author contributions: Concept- M.M.O.R., T.D.A.; Design- T.D.A., M.M.O.R.; Supervision- M.M.O.R.; Data collection and/or processing- T.D.A., S.C.P.; Analysis and/or interpretation- T.D.A., M.A.H., S.C.P.; Literature search- T.D.A., S.C.P.; Writing manuscript- T.D.A., M.M.O.R., M.A.H.; Critical review- M.M.O.R., M.A.H.

Conflict of interest statement: Authors have no competing interest to declare.

\section{REFERENCES}

[1] Querfurth HW, LaFerla FM. Alzheimer's disease. N Engl J Med. 2010; 362(4): 329-344. [CrossRef]

[2] Wang Y, Shi Y, Wei H. Calcium dysregulation in Alzheimer's disease: A target for new drug development. J Alzheimers Dis Parkinsonism. 2017; 7(5): 374. [CrossRef]

[3] Bu G. Apolipoprotein E and its receptors in Alzheimer's disease: pathways, pathogenesis and therapy. Nat Rev Neurosci. 2009; 10: 333-344. [CrossRef]

[4] Pini L, Pievani M, Bocchetta M, Altomare D, Bosco P, Cavedo E, Galluzzi S, Marizzoni M, Frisoni GB. Brain atrophy in Alzheimer's disease and aging. Ageing Res Rev. 2016; 30: 25-48. [CrossRef]

[5] Hardy J, Selkoe DJ. The amyloid hypothesis of Alzheimer's disease: progress and problems on the road to therapeutics. Science. 2002; 297: 353-356. [CrossRef]

[6] Price JL, McKeel DW Jr, Buckles VD, Roe CM, Xiong C, Grundman M, Hansen LA, Petersen RC, Parisi JE, Dickson DW, Smith CD, Davis DG, Schmitt FA, Markesbery WR, Kaye J, Kurlan R, Hulette C, Kurland BF, Higdon R, Kukull W, Morris JC. Neuropathology of nondemented aging: presumptive evidence for preclinical Alzheimer disease. Neurobiol Aging. 2009; 30: 1026-1036. [CrossRef]

[7] Hardy J, Allsop D. Amyloid deposition as the central event in the aetiology of Alzheimer's disease. Trends Pharmacol Sci. 1991; 12(10): 383-388. [CrossRef]

[8] Teng FY, Tang BL. Widespread gamma-secretase activity in the cell, but do we need it at the mitochondria? Biochem Biophys Res Commun. 2005; 328: 1-5. [CrossRef]

[9] Goodman Y, Mattson MP. Secreted forms of beta-amyloid precursor protein protect hippocampal neurons against amyloid beta-peptide-induced oxidative injury. Exp Neurol. 1994; 128(1): 1-12. [CrossRef]

[10] Lustbader JW, Cirilli M, Lin C, Xu HW, Takuma K, Wang N, Caspersen C, Chen X, Pollak S, Chaney M, Trinchese F, Liu S, Gunn-Moore F, Lue LF, Walker DG, Kuppusamy P, Zewier ZL, Arancio O, Stern D, Yan SS, Wu H. J. W. ABAD directly links A $\beta$ to mitochondrial toxicity in Alzheimer's disease. Science. 2004; 304(5669): 448-452. [CrossRef]

[11] Caricasole A, Copani A, Caruso A, Caraci F, Iacovelli L, Sortino MA, Terstappen GC, Nicoletti F. The Wnt pathway, cell-cycle activation and beta-amyloid: novel therapeutic strategies in Alzheimer's disease? Trends Pharmacol Sci. 2003; 24(5): 233-238. [CrossRef]

[12] Xie L, Helmerhorst E, Taddei K, Plewright B, Van Bronswijk W, Martins R. Alzheimer's beta-amyloid peptides compete for insulin binding to the insulin receptor. J Neurosci. 2002; 22(10): 221. [CrossRef] 
[13] Kim JW, Lee JE, Kim MJ, Cho EG, Cho SG, Choi EJ. Glycogen synthase kinase 3 beta is a natural activator of mitogenactivated protein kinase/extracellular signal-regulated kinase kinasekinase 1 (MEKK1). J Biol Chem. 2003; 278(16): 13995-14001. [CrossRef]

[14] Bamberger ME, Landreth GE. Microglial interaction with beta-amyloid: implications for the pathogenesis of Alzheimer's disease. Microsc Res Tech. 2001; 54(2): 59-70. [CrossRef]

[15] Cataldo AM, Petanceska S, Terio NB, Peterhoff CM, Durham R, Mercken M, Mehta PD, Buxbaum J, Haroutunian V, Nixon RA. Abeta localization in abnormal endosomes: association with earliest Abeta elevations in AD and Down syndrome Neurobiol Aging. 2004; 25(10): 1263-1272. [CrossRef]

[16] McLean CA, Cherny RA, Fraser FW, Fuller SJ, Smith MJ, Beyreuther K, Bush AI, Masters CL. Soluble pool of Abeta amyloid as a determinant of severity of neurodegeneration in Alzheimer's disease. Ann Neurol. 1999; 46(6): 860-866. [CrossRef]

[17] Gouras GK, Tsai J, Naslund J, Vincent B, Edgar M, Checler F, Greenfield JP, Haroutunian V, Buxbaum JD, Xu H, Greengard P, Relkin NR. Intraneuronal A $\beta 42$ accumulation in human brain. Am J Pathol. 2000; 156(1): 15-20. [CrossRef]

[18] Götz J, Streffer JR, David D, Schild A, Hoerndli F, Pennanen L, Kurosinski P, Chen F. Transgenic animal models of Alzheimer's disease and related disorders: histopathology, behavior and therapy. Mol Psychiatry. 2004; 9(7): 664-683. [CrossRef]

[19] Walsh DM, Klyubin I, Fadeeva JV, Cullen WK, Anwyl R, Wolfe MS, Rowan MJ, Selkoe DJ. Naturally secreted oligomers of amyloid beta protein potently inhibit hippocampal long-term potentiation in vivo. Nature. 2002; 416(6880): 535-639. [CrossRef]

[20] Iijima K, Liu HP, Chiang AS, Hearn SA, Konsolaki M, Zhong Y. Dissecting the pathological effects of human A $\beta 40$ and A $\beta 42$ in Drosophila: a potential model for Alzheimer's disease. Proc Natl Acad Sci U S A. 2004; 101(17): 66236628. [CrossRef]

[21] Dickey CA, Loring JF, Montgomery J, Gordon MN, Eastman PS, Morgan D. Selectively reduced expression of synaptic plasticity-related genes in amyloid precursor protein + presenilin-1 transgenic mice. J Neurosci. 2003; 23(12): 5219-5226. [CrossRef]

[22] Gasparini L, Gouras GK, Wang R, Gross RS, Beal MF, Greengard P, Xu H. Stimulation of $\beta$-amyloid precursor protein trafficking by insulin reduces intraneuronal $\beta$-amyloid and requires mitogen-activated protein kinase signaling. J Neurosci. 2001; 21(8): 2561-2570. [CrossRef]

[23] Kamal A, Stokin GB, Yang Z, Xia CH, Goldstein LS. Axonal transport of amyloid precursor protein is mediated by direct binding to the kinesin light chain subunit of kinesin-I. Neuron. 2000; 28(2): 449-459. [CrossRef]

[24] Stamer K, Vogel R, Thies E, Mandelkow E, Mandelkow EM. Tau blocks traffic of organelles, neurofilaments, and APP vesicles in neurons and enhances oxidative stress. J Cell Biol. 2002; 156(6): 1051-1063. [CrossRef]

[25] Stokin GB, Lillo C, Falzone TL, Brusch RG, Rockenstein E, Mount SL, Raman R, Davies P, Masliah E, Williams DS, Goldstein LS. Axonopathy and transport deficits early in the pathogenesis of Alzheimer's disease. Science. 2005; 307(5713): 1282-1288. [CrossRef]

[26] Glenner GG, Wong CW. Alzheimers-Disease and Down's syndrome: sharing of a unique cerebrovascular amyloid fibril protein. Biochem Biophys Res Commun. 1984; 122(3): 1131-1135. [CrossRef]

[27] Goate A, Chartier-Harlin MC, Mullan M, Brown J, Crawford F, Fidani L, Giuffra L, Haynes A, Irving N, James L. Segregation of a missense mutation in the amyloid precursor protein gene with familial AD. Nature. 1991; 349(6311): 704-706. [CrossRef]

[28] Herrup k. The case for rejecting the amyloid cascade hypothesis. Nature. 2015; 18(6): 794-799. [CrossRef]

[29] Swerdlow RH, Burns JM, Khanb SM. The Alzheimer's Disease Mitochondrial Cascade Hypothesis: Progress and Perspectives. Biochim Biophys Acta. 2014; 1842(8): 1219-1231. [CrossRef]

[30] Cheng Y, Bai F. The association of tau with mitochondrial dysfunction in Alzheimer's disease. Front Neurosci. 2018; 12: 163. [CrossRef]

[31] Swerdlow RH. Mitochondria and cell bioenergetics: increasingly recognized components and a possible etiologic cause of Alzheimer's disease. Antioxid Redox Signal. 2012; 16: 1434-1455. [CrossRef]

[32] Coskun PE, Beal MF, Wallace DC. Alzheimer's brains harbor somatic mtDNA control-region mutations that suppress mitochondrial transcription and replication. Proc Natl Acad Sci USA. 2004; 101: 10726-10731. [CrossRef] 
[33] Corral-Debrinski M, Horton T, Lott MT, Shoffner JM, McKee AC, Beal MF, Graham BH, Wallace DC. Marked changes in mitochondrial DNA deletion levels in Alzheimer brains. Genomics. 1994; 23: 471-476. [CrossRef]

[34] Hamblet NS, Castora FJ. Elevated levels of the Kearns-Sayre syndrome mitochondrial DNA deletion in temporal cortex of Alzheimer's patients. Mutat Res. 1997; 379: 253-262. [CrossRef]

[35] Bender A, Krishnan KJ, Morris CM, Taylor GA, Reeve AK, Perry RH, Jaros E, Hersheson JS, Betts J, Klopstock T, Taylor RW, Turnbull DM. High levels of mitochondrial DNA deletions in substantia nigra neurons in aging and Parkinson disease. Nat Genet. 2006; 38: 515-517. [CrossRef]

[36] Kraytsberg Y, Kudryavtseva E, McKee AC, Geula C, Kowall NW, Khrapko K. Mitochondrial DNA deletions are abundant and cause functional impairment in aged human substantia nigra neurons. Nat Genet. 2006; 38: 518-520. [CrossRef]

[37] Corrada MM, Brookmeyer R, Berlau D, Paganini-Hill A, Kawas CH. Prevalence of dementia after age 90: results from the 90+ study. Neurology. 2008; 71: 337-343. [CrossRef]

[38] Berridge MJ. Calcium hypothesis of Alzheimer's disease. Pflügers Arch. 2010; 459(3): 441-449. [CrossRef]

[39] Bezprozvanny I. Calcium Signaling and Neurodegeneration. Acta Naturae. 2010; 2(1): 72-82.

[40] Berridge MJ. Neuronal calcium signaling. Neuron. 1998; 21: 13-26. [CrossRef]

[41] Landfield PW. 'Increased calcium-current' hypothesis of brain aging. Neurobiol Aging. 1987; 8: 346-347. [CrossRef]

[42] Disterhoft JF, Thompson LT, Weiss C, Moyer JM Jr, Zee EVD, Carrillo M, Kronfrost-Collins M, Power J. The Caicium hypothesis for AD: Insights from human and animal studies. Neurosci Res Commun. 1995; 17(2):121-131.

[43] Vassar R, Bennett BD, Babu-Khan S, Kahn S, Mendiaz EA, Denis P, Teplow DB, Ross S, Amarante P, Loeloff R, Luo Y, Fisher S, Fuller J, Edenson S, Lile J, Jarosinski MA, Biere AL, Curran E, Burgess T, Louis JC, Collins F, Treanor J, Rogers G, Citron M. Beta-secretase cleavage of Alzheimer's amyloid precursor protein by the transmembrane aspartic protease BACE. Science. 1999; 286: 735-741. [CrossRef]

[44] Brzyska M and Elbaum D. Dysregulation of calcium in Alzheimers disease. Acta Neurobiol. 2003; 63: 171-183.

[45] Alzheimer's research-intracellular calcium store malfunction leads to brain hyperactivity. Medical press.https:/ / medicalxpress.com/news/2018-02-alzheimer-researchintracellular-calcium-malfunction-brain.html (accessed February 9, 2018)

[46] Thomas E Cope. How Alzheimer's disease spreads throughout the brain-new study. http://theconversation.com/how-alzheimers-disease-spreads-throughout-the-brain-new-study-89692 (accessed January 5, 2018)

[47] Xie C and Miyasaka T. The Role of the Carboxyl-Terminal Sequence of Tau and MAP2 in the Pathogenesis of Dementia. Front Mol Neurosci. 2016; 9: 158. [CrossRef]

[48] Ballatore C, Lee V-Y, Trojanowski J. Tau mediated neurodegeneration in Alzheimers disease and related disorders. Nat Rev Neurosci. 2007; 8: 663-672. [CrossRef]

[49] Buee L, Bussiere T, Buee-Scherrer V, Delacourte A, Hof P. Tau protein isoforms, phosphorylation and role in neurodegenerative disorders. Brain Res Rev. 2000; 33: 95-130. [CrossRef]

[50] Mudher M, Lovestone S. Alzheimer's disease- do tauists and Baptists finally shake hands? Trends Neurosci. 2002; 25:22-26. [CrossRef]

[51] Maccioni RB, Farı́as G, Morales I, Navarrete L. The Revitalized Tau Hypothesis on AD. Arch Med Res. 2010; 41; 226231. [CrossRef]

[52] Delacourte A. The natural and molecular history of AD. J Alzheimers Dis. 2006; 9: 187-194. [CrossRef]

[53] Rapoport M, Dawson HN, Binder LI, Vitek MP, Ferreira A. Tau is essential to beta-amyloid-induced neurotoxicity. Proc Natl Acad Sci USA. 2002; 99, 6364-6369. [CrossRef]

[54] Koopman WJ, Nijtmans LG, Dieteren CE, Roestenberg P, Valsecchi F, Smeitink JA, Willems PH. Mammalian mitochondrial complex I: biogenesis, regulation, and reactive oxygen species generation. Antioxid Redox Signal. 2010; 12(12): 1431-1470. [CrossRef]

[55] Padurariu M, Ciobica A, Lefter R, Serban IL, Stefanescu C, Chirita R. The Oxidative Stress Hypothesis In Alzheimers Disease. Psychiatria Danubina. 2013; 25(4): 401-409.

[56] Wojsiat J, Zoltowska KM, Kaszub KL, Wojda U. Oxidant/Antioxidant imbalance in Alzheimer's disease: therapeutic and diagnostic prospects. Oxid Med Cell Longev. 2018; 1-16. [CrossRef] 
[57] Doorn JA and Petersen DR. Covalent adduction of nucleophilic amino acids by 4-hydroxynonenal and 4-oxononenal. Chem Biol Interact. 2003; 143-144: 93-100. [CrossRef]

[58] Resende R, Moreira P, Proença T, Deshpande A, Busciglio J, Pereira C, Oliveira CR. Brain oxidative stress in a tripletransgenic mouse model of Alzheimer disease. Free Radic Biol Med. 2008; 44(12): 2051-2057. [CrossRef]

[59] Greenough MA, Camakaris J, Bush AI. Metal dyshomeostasis and oxidative stress in Alzheimer's disease. Neurochem Int. 2013; 62: 540-555. [CrossRef]

[60] Huang W, Zhang X, Chen W. Role of oxidative stress in Alzheimer's disease. Biomed Rep. 2016; 4(5): 519-522. [CrossRef]

[61] Craddock TJ, Tuszynski JA, Chopra D, Casey N, Goldstein LE, Hameroff SR, Tanzi RE. The zinc dyshomeostasis hypothesis of Alzheimer's disease. PLoS One. 2012; 7: 33552. [CrossRef]

[62] Yamamoto A, Shin RW, Hasegawa K, Naiki H, Sato H, Yoshimasu F, Kitamoto T. Iron (III) induces aggregation of hyperphosphorylated tau and its reduction to iron (II) reverses the aggregation: implications in the formation of neurofibrillary tangles of Alzheimer's disease. J Neurochem. 2002; 82: 1137-1147. [CrossRef]

[63] Jomova K, Vondrakova D, Lawson M, Valko M. Metals, oxidative stress and neurodegenerative disorders. Mol Cell Biochem. 2010; 345: 91-104. [CrossRef]

[64] Fleming JL, Phiel CJ, Toland AE. The role for oxidative stress in aberrant DNA methylation in Alzheimer's disease.Curr Alzheimer Res. 2012; 9: 1077-1096. [CrossRef]

[65] Takuma K, Yao J, Huang J, Xu H, Chen X, Luddy J, Trillat AC, Stern DM, Arancio O, Yan SS. ABAD enhances A $\beta$ induced cell stress via mitochondrial dysfunction. The FASEB Journal. 2005; 19(6):597-598. [CrossRef]

[66] Orth M and Bellosta S. Cholesterol: Its Regulation and Role in Central Nervous System Disorders. Cholesterol. 2012; 2012: 292598. [CrossRef]

[67] Testa G, Staurenghi E, Zerbinati C, Gargiulo S, Iuliano L, Giaccone G, Fantò F, Poli G, Leonarduzzi G, Gamba P. Changes in brain oxysterols at different stages of Alzheimer's disease: Their involvement in neuroinflammation. Redox Biol. 2016; 10: 24-33. [CrossRef]

[68] Xue-Shan Z, Juan P, Qi W, Zhong R, Li-Hong P, Zhi-Han T, Zhi-Sheng J, Gui-Xue W, Lu-Shan L. Imbalanced cholesterol metabolism in AD. Clin Chim Acta. 2016; 456:107-114. [CrossRef]

[69] Hascalovici JR, Vaya J, Khatib S, Holcroft CA, Zukor H, Song W, Arvanitakis Z, Bennett DA, Schipper HM. Brain sterol dysregulation in sporadic AD and MCI: relationship to heme oxygenase-1. J Neurochem. 2009; 110:1241-1253. [CrossRef]

[70] Lütjohann D, Meichsner S, Pettersson H. Lipids in AD and their potential for therapy. J Clin Lipidol. 2012; 7(1):6578. [CrossRef]

[71] Habchi J, Chia S, Galvagnion C, Michaels TCT, Bellaiche MMJ, Ruggeri FS, Sanguanini M, Idini I, Kumita JR, Sparr E, Linse S, Dobson CM, Knowles TPJ, Vendruscolo M. Cholesterol catalyses A $\beta 42$ aggregation through a heterogeneous nucleation pathway in the presence of lipid membranes. Nat Chem. 2018; 10: 673-683. [CrossRef]

[72] Heneka MT, Carson MJ, El Khoury J, Landreth GE, Brosseron F, Feinstein DL, Jacobs AH, Wyss-Coray T, Vitorica J, Ransohoff RM, Herrup K, Frautschy SA, Finsen B, Brown GC, Verkhratsky A, Yamanaka K, Koistinaho J, Latz E, Halle A, Petzold GC, Town T, Morgan D, Shinohara ML, Perry VH, Holmes C, Bazan NG, Brooks DJ, Hunot S, Joseph B, Deigendesch N, Garaschuk O, Boddeke E, Dinarello CA, Breitner JC, Cole GM, Golenbock DT, Kummer MP. Neuroinflammation in AD. Lancet Neurol. 2015; 14(4): 388-405. [CrossRef]

[73] Zotova E, Nicoll JA, Kalaria R, Holmes C, Boche D. Inflammation in AD: relevance to pathogenesis and therapy. Alzheimers Res Ther. 2010; 2(1): 1. [CrossRef]

[74] Ho GJ, Drego R, Hakimian E, Masliah E. Mechanisms of cell signaling and inflammation in AD. Curr Drug Targets Inflamm Allergy. 2005; 4(2): 247-56. [CrossRef]

[75] Rezai-Zadeh K, Gate D, Town T. CNS infiltration of peripheral immune cells: D-Day for neurodegenerative disease? J Neuroimmune Pharmacol. 2009; 4(4): 462-475. [CrossRef]

[76] Mietelska-Porowska A and Wojda U. T Lymphocytes and Inflammatory Mediators in the Interplay between Brain and Blood in Alzheimer's Disease: Potential Tools of New Biomarkers. J Immunol Res. 2017; 4626540: 1-17. [CrossRef]

[77] Rosenberg GA. Neurological diseases in relation to the blood brain barrier. J Cereb Blood Flow Metab. 2012; 32(7): 1139-1151. [CrossRef] 
[78] Fisher Y, Strominger I, Biton S, Namirovsky A, Baron R, Monsonego A. Th1 polarization of T cells rejected into the cerebrospinal fluid induces brain immune-surveillance. J Immunol. 2014; 192(1): 92-102. [CrossRef]

[79] McManus RM, Higgins SC, Mills KHG, MA Lynch. Respiratory infection promotes T cell infiltration and amyloid $\beta$ deposition in APP/PS1 mice. Neurobiol Aging. 2014; 35(1): 109-121. [CrossRef]

[80] Swerdlow RH. Is aging part of Alzheimer's disease, or is Alzheimer's disease part of aging. Neurobiol Aging. 2007; 28: 1465-1480. [CrossRef]

[81] Hendrie HC. Epidemiology of dementia and Alzheimer's disease. Am J Geriatr Psychiatry. 1998; 6: 3-18. [CrossRef]

[82] Hayflick L. Biological aging is no longer an unsolved problem. Ann NY Acad Sci. 2007; 1100: 1-13. [CrossRef]

[83] Hedden T, Gabrieli JD. Insights into the aging mind: A view from cognitive neuroscience. Nat Rev Neurosci. 2004; 5:87-96. [CrossRef]

[84] Thibault O, Gant JC, Landfield PW. Expansion of the calcium hypothesis of brain aging and Alzheimer's disease: minding the store. Aging Cell. 2007; 6(3): 307-317. [CrossRef]

[85] Kritchevsky SB, Muldoon MF. Oxidative stress and aging: still a hypothesis. J Am Geriatr Soc. 1996; 44: 873-875. [CrossRef]

[86] Wang Y, Yan T, Lu H, Yin W, Lin B, Fan W, Zhang X, Fernandez-Funez P. Lessons from Anti-Amyloid- $\beta$ Immunotherapies in Alzheimer Disease: Aiming at a Moving Target. Neurodegener Dis. 2017; 17(6): 242-250. [CrossRef]

This is an open access article which is publicly available on our journal's website under Institutional Repository at http://dspace.marmara.edu.tr. 